\title{
Proceeding
}

Supplementary Issue: Summer Conferences of Sports Science. Costa Blanca Sports Science Events, 25-26 September 2020. Alicante, Spain.

\section{The educational value of the rules in handball}

\author{
GAETANO RAIOLA ${ }^{1} \triangle$, PIETRO LUIGI INVERNIZZI², RAFFAELE SCURATI², SIMONA FATTORE1 \\ ${ }^{1}$ Department of Human, Philosophical and Education Sciences, University of Salerno, Italy \\ 2University of Milan, Italy
}

\begin{abstract}
The game rules of team sports and the technical and tactical methods applicable to them are indispensable for practicing competitive sports. The correct competition arose from the automatic mechanism of the sanction following the infringement of a game rule which is also aided by the relational dynamics of the individual members of the group who demand the application of the rule to continue playing. The competition can also be self-regulated by the two groups who compete for the victory without even the decisive action of the referee as always happens in training activities. This phenomenon is found only in those contexts where the rule is necessary and alone sufficient to ensure the orderly development of activities. The objective of the study is to identify the significant elements of the handball game rules, and the related technical and tactical behaviours, to identify an inventory of significant behaviours. The method is documentary archival research for the analysis of the game rules of the team sport in question, and a subsequent comparative method between grids of indicators, descriptors and weights that classify rule, technique and tactics. The expected results will focus on the appropriate presence of the significant elements and the commonality or discrepancy between team sports. The data is useful for measuring the quantity of significant behaviours in order to qualitatively elaborate the value of each of them with respect to the other current behaviours of quantitative performance and establish the connections.

Keywords: Game rules; Basic technical skills; Principles of individual tactics; Principles of collective tactics.

\section{Cite this article as:}

Raiola, G., Invernizzi, P.L., Scurati, R., \& Fattore, S. (2020). The educational value of the rules in handball. Journal of Human Sport and Exercise, 15(4proc), S1214-S1223. doi:https://doi.org/10.14198/ihse.2020.15.Proc4.23
\end{abstract}

Corresponding author. Department of Human, Philosophical and Education Sciences, University of Salerno, Italy. http://orcid.org/0000-0002-7659-1674

E-mail: raiolagaetano@libero.it

Abstract submitted to: Spring Conferences of Sports Science. Costa Blanca Sports Science Events, 19-20 June 2020. Alicante, Spain.

JOURNAL OF HUMAN SPORT \& EXERCISE ISSN 1988-5202

(c) Faculty of Education. University of Alicante

doi:10.14198/jhse.2020.15.Proc4.23

S1214 | 2020| Proc4 | VOLUME 15

C 2020 University of Alicante 


\section{INTRODUCTION}

The regulation of the game of handball, in its modern form, dates back to 1920 and is due to Karl Diem, one of the organizers of the 1936 Berlin Olympics, an edition in which handball became an Olympic sport. The game initially took place outdoors and the teams consisted of eleven players, later it began to play indoors and the players became seven for each team (Gao \& He, 2004). This latest version had already been adopted by the Scandinavian countries for reasons related to environmental conditions. The birth of handball in Italy dates back to 1965, but the sport spread between 1969 and 1970, when the first championship was held (Debanne, 2014).

Handball is a very fast game, based on continuous changes of direction that engage the players not only on a physical level, with runs, sprints, jumps, throws, but also on a mental level (Severino, et al., 2019), requiring short reaction times, rapid analysis and choice, tactical skills and team spirit (Schrapf \& Tilp, 2013; Skarbalius, 2013). Technique is the fundamental element of the game of handball and, even if only under certain conditions, it can also be used independently to develop a good game system. To start playing handball it is sufficient to learn the basic technical skills (Sgrò et al., 2019): the reception and catching of the ball, dribbling, passing, shooting and for those who play between the goal posts, saves. This happens because it is the tactic itself that depends on the technique. The attitudes that players take are a direct consequence of the characteristics of the game (Gutierrez-Davila et al., 2011). Sometimes, within certain limits, it can also happen that a good game tactic can make up for certain technical deficiencies both individual and collective. When choosing tactics it is necessary to take into account the many qualities and characteristics of individual players (Altavilla et al., 2017) since it is shown that even the best tactics is bound to fail if it is not adequate to the technical preparation of players (Zhao et al., 2008). Therefore, it is of particular importance to know both the level of the individual and of the opposing formation in general (Rogulj et al., 2004).

The more players are good and experienced in the role and in the task entrusted to him, the more we will approach the concept of team-collective. Every player must be a danger to his opponents but must also remember to interact continuously with his teammates in order to increase exponentially the danger of his entire team. Players and training that put these elementary concepts into practice certainly manage to create a strong point and a first advantage over opponents (Wagner et al, 2011). It is also useful to remember how physical fatigue reduces players' abilities (Altavilla, 2020). For this reason, a good coach must always remember that assigning tactical tasks beyond the possibilities of individuals is absolutely harmful and limiting (Esposito et al, 2020). Speaking of the importance of physical preparation, it is also mandatory to remember a fundamental concept: all players must be able to play both in attack and in defence (Granero-Gallegos et al., 2017). When a team (but also individual players) boast greater speed than the opponent, the tactic to be preferred is that of a quick attack (Fradet et al., 2003). Only when students have achieved sufficient knowledge of the rules and will be able to apply the fundamentals (Ferrara et al., 2019) and simpler game schemes, at least half of the hours scheduled for handball will be dedicated to playing with real matches (Raiola \& D'Isanto, 2016). In the game it will be appropriate to evaluate (Ceruso et al., 2019) and possibly have the teammates evaluate, the overall execution (D'Isanto et al., 2019).

The judgment, also called "game logic", must include the evaluation of commitment, respect for the rules, self-control, dynamism, imagination (D'Elia et al., 2020, Raiola et al, 2020), effectiveness in moving with and without the ball; consequently little importance will be given to errors due to a not perfect technique. The assessment (Sgrò et al., 2017) must be adapted to the skills and competences acquired by each one (Raiola, 2015). 


\section{Aim of study}

The purpose of this study is to identify the significant elements of the game rules and the related technical tactical behaviours to be adopted in the various match situations in team handball play. All this allows us to define an inventory of significant behaviours to be subjected to qualitative processing. The value of each of them will be measured with respect to the other behaviours of qualitative performance.

\section{MATERIAL AND METHODS}

On the one hand, the method involves archival research with a documentary approach for the analysis of the rules that characterize the team sport in question; on the other hand, on the other hand, it provides a comparison between grids of indicators, descriptors and weights (i.e. the degree of connection between indicator and descriptor) which allows to classify the rule, technique and tactics. In a first phase, the analysis of the handball game rules was conducted, with which we tried to establish a connection with the technical and tactical aspects necessary to achieve the specific objective set. The identified rule represented the indicator, while the technical and tactical proposals represented the first and second descriptor respectively. The degree of connection between the indicator and the descriptor was then assessed, assigning a qualitative value between three choices: close, medium or low connection. In the second phase of the research, the relationship of each of the previously identified elements with the performance data was descriptively identified. In practice, the degree of physical effort, the degree of strength and that of speed were assessed for each of the indicators-descriptors identified, assigning also in this case a qualitative value among the possible alternatives: maximum, average and minimum commitment. The data is therefore useful for measuring the quantity of significant behaviours to qualitatively elaborate the value of each of them with respect to the other current behaviours of quantitative performance and to establish the connections. The results may be useful for any reflections and focus on the reproducibility of the investigated mechanism to other social activities through an educational and formative action.

\section{RESULTS}

Table 1. Indicator, descriptors, connection between indicator and descriptor.

\begin{tabular}{|l|l|l|l|l|l|l|}
\hline Indicator & 1st Descriptor & 2nd Descriptor & $\begin{array}{l}\text { Connection } \\
\text { Indicator- } \\
\text { Descriptor }\end{array}$ & $\begin{array}{l}\text { Connection with the performance } \\
\text { data }\end{array}$ \\
\hline Rule & $\begin{array}{l}\text { Technique } \\
\text { proposal }\end{array}$ & Tactical proposal & Weight & $\begin{array}{l}\text { Degree of } \\
\text { physical } \\
\text { commitment }\end{array}$ & Rule & $\begin{array}{l}\text { Technique } \\
\text { proposal }\end{array}$ \\
\hline $\begin{array}{l}\text { The spherical ball } \\
\text { must be made of } \\
\text { leather or synthetic } \\
\text { material. }\end{array}$ & $\begin{array}{l}\text { Train the } \\
\text { sensitivity of the } \\
\text { grip by handing } \\
\text { the ball to the } \\
\text { teammate who } \\
\text { must exercise a } \\
\text { hold from above }\end{array}$ & $\begin{array}{l}\text { Situational } \\
\text { exercise for } \\
\text { maintaining } \\
\text { possession. Ability } \\
\text { to manage the ball, } \\
\text { with an opponent, } \\
\text { in his own space. }\end{array}$ & Close & Medium & Medium & Maximum \\
\hline $\begin{array}{l}\text { The ball cannot be } \\
\text { held for more than } \\
\text { three seconds in } \\
\text { the hand when } \\
\text { stationary, and no } \\
\text { more than three } \\
\text { steps can be taken }\end{array}$ & $\begin{array}{l}\text { One ball for each } \\
\text { pair - Front } \\
\text { passes in slow } \\
\text { running and } \\
\text { continuous back } \\
\text { and ahead }\end{array}$ & $\begin{array}{l}\text { The same by } \\
\text { varying the type of } \\
\text { passage; with two } \\
\text { hands, at the side, } \\
\text { bounced, rolled, } \\
\text { backwards, of foot, } \\
\text { with aerial }\end{array}$ & Close & Medium & Medium & Maximum \\
\hline
\end{tabular}




\begin{tabular}{|c|c|c|c|c|c|c|}
\hline $\begin{array}{l}\text { without passing it } \\
\text { or bouncing it on } \\
\text { the ground }\end{array}$ & & $\begin{array}{l}\text { collection, } \\
\text { asymmetrical, etc. }\end{array}$ & & & & \\
\hline $\begin{array}{l}\text { The attacking team } \\
\text { must try to make a } \\
\text { goal without } \\
\text { entering the } \\
\text { goalkeeper's area } \\
\text { or in any case, if } \\
\text { he shoots in a } \\
\text { hurry, the player } \\
\text { can enter by } \\
\text { jumping into the } \\
\text { goalkeeper's area } \\
\text { but releasing the } \\
\text { ball before it } \\
\text { touches any part of } \\
\text { the body, the } \\
\text { ground within the } \\
\text { goal area. }\end{array}$ & $\begin{array}{l}\text { Two rows of } \\
\text { players on the } \\
\text { wing position, } \\
\text { let's go } \\
\text { alternating, you } \\
\text { receive a pass } \\
\text { from a } \\
\text { goalkeeper, go } \\
\text { around a cone in } \\
\text { the middle of the } \\
\text { field and you go } \\
\text { to shoot in } \\
\text { elevation outside } \\
9 \text { meters }\end{array}$ & $\begin{array}{l}\text { Three-player attack } \\
\text { combinations (full- } \\
\text { back-centre-back) } \\
\text { with change of } \\
\text { place without the } \\
\text { ball and shot }\end{array}$ & Close & Maximum & $\begin{array}{l}\text { Maximu } \\
\mathrm{m}\end{array}$ & Maximum \\
\hline $\begin{array}{l}\text { There are } \\
\text { temporary } \\
\text { suspensions from } \\
\text { the playing field } \\
\text { which consist of } \\
\text { two-minute } \\
\text { periods. At the } \\
\text { third temporary } \\
\text { ban, the player is } \\
\text { disqualified for the } \\
\text { remainder of the } \\
\text { match. }\end{array}$ & $\begin{array}{l}\text { Game to improve } \\
\text { speed and lateral } \\
\text { vision. }\end{array}$ & $\begin{array}{l}\text { Situational work - } \\
\text { 3v2 with defenders } \\
\text { in line on } 6 \text { meters. }\end{array}$ & Close & Maximum & $\begin{array}{l}\text { Maximu } \\
\mathrm{m}\end{array}$ & Maximum \\
\hline $\begin{array}{l}\text { The nine-meter } \\
\text { foul is foreseen } \\
\text { which is beaten } \\
\text { with the defence } \\
3 \mathrm{~m} \text { from the ball } \\
\text { and the attack all } \\
\text { outside the } 9 \mathrm{~m} \text { line }\end{array}$ & $\begin{array}{l}\text { Exercise } \\
\text { Front shot and } \\
\text { shot performed } \\
\text { from outside } \\
\text { areas }\end{array}$ & $\begin{array}{l}\text { Each successful } \\
\text { shot is equal to } \\
\text { points: sx/dx } 2 \\
\text { points high; in high } \\
\text { centre /sx, } \\
\text { sideways/dx-sx } 1 \\
\text { point. If the player } \\
\text { manages to shoot } \\
\text { from outside } \\
\text { positions a left or } \\
\text { right the points } \\
\text { obtained can be } \\
\text { multiplied by two }\end{array}$ & Close & Medium & $\begin{array}{l}\text { Maximu } \\
\mathrm{m}\end{array}$ & Maximum \\
\hline $\begin{array}{l}\text { When a defender } \\
\text { enters the goal } \\
\text { area with clear } \\
\text { defensive intent, } \\
\text { the } 7 \mathrm{~m} \text { shot, } \\
\text { commonly known } \\
\text { as a "penalty", is } \\
\text { granted with one }\end{array}$ & $\begin{array}{l}\text { The players line } \\
\text { up behind the } \\
\text { penalty-shot line, } \\
\text { forming two } \\
\text { columns. Each } \\
\text { player has a ball. } \\
\text { One after the } \\
\text { other, they throw }\end{array}$ & $\begin{array}{l}\text { Search for } \\
\text { precision. Those of } \\
\text { the first battery aim } \\
\text { at the upper right } \\
\text { corner of the door, } \\
\text { while those of the } \\
\text { second at the } \\
\text { upper left corner, }\end{array}$ & Close & Maximum & $\begin{array}{l}\text { Maximu } \\
\mathrm{m}\end{array}$ & Maximum \\
\hline
\end{tabular}




\begin{tabular}{|c|c|c|c|c|c|c|}
\hline $\begin{array}{l}\text { foot on the } 7 \mathrm{~m} \text { line } \\
\text { (without touching } \\
\text { it) and with only } \\
\text { the goalkeeper in } \\
\text { front, who does not } \\
\text { can exceed } 4 \\
\text { meters of the door. }\end{array}$ & $\begin{array}{l}\text { the balls into the } \\
\text { goal. }\end{array}$ & $\begin{array}{l}\text { then the lower right } \\
\text { and lower left. }\end{array}$ & & & & \\
\hline $\begin{array}{l}\text { In marking the } \\
\text { opponent, the } \\
\text { regulation prohibits } \\
\text { pulling him, } \\
\text { blocking his way } \\
\text { with your hands or } \\
\text { arms and } \\
\text { snatching the ball } \\
\text { from his hand }\end{array}$ & $\begin{array}{l}\text { In pairs, one } \\
\text { completes the } \\
\text { penetration } \\
\text { trajectory, the } \\
\text { other defends in } \\
\text { control. }\end{array}$ & $\begin{array}{l}\text { Three defenders } \\
\text { and three rows of } \\
\text { forwards in the } \\
\text { positions of winger. } \\
\text { The attackers have } \\
\text { the task of } \\
\text { circulating the ball } \\
\text { even under the } \\
\text { contact of the } \\
\text { defenders; the } \\
\text { defenders disturb } \\
\text { with slight contacts } \\
\text { and conflicts on the } \\
\text { person. }\end{array}$ & Close & Maximum & $\begin{array}{l}\text { Maximu } \\
\mathrm{m}\end{array}$ & Maximum \\
\hline $\begin{array}{l}\text { The player in } \\
\text { possession of the } \\
\text { ball cannot pass } \\
\text { the ball to his } \\
\text { goalkeeper when } \\
\text { he is in the goal } \\
\text { area. }\end{array}$ & $\begin{array}{l}\text { Exercises on the } \\
\text { crosses between } \\
\text { attackers }\end{array}$ & $\begin{array}{l}\text { Three on the wing } \\
\text { sector: full-back } \\
\text { crosses with } \\
\text { central who } \\
\text { penetrates and } \\
\text { discharges on the } \\
\text { wing. }\end{array}$ & Close & Medium & Medium & Maximum \\
\hline $\begin{array}{l}\text { A team is not } \\
\text { allowed to maintain } \\
\text { possession of the } \\
\text { ball without there } \\
\text { being an obvious } \\
\text { attempted attack or } \\
\text { shot on goal. }\end{array}$ & $\begin{array}{l}\text { Exchange of the } \\
\text { ball in the race } \\
\text { with passing by } \\
\text { establishing eye } \\
\text { contact with a } \\
\text { teammate. }\end{array}$ & $\begin{array}{l}\text { 3vs3 to free the } \\
\text { pivot. The central } \\
\text { zone is attacked in } \\
\text { three against three } \\
\text { until the pivot (4th } \\
\text { man) enters the } \\
\text { zone. At this point, } \\
\text { the pivot must be } \\
\text { released or he } \\
\text { create an } \\
\text { advantageous } \\
\text { condition for the } \\
\text { penetration of a } \\
\text { full-back }\end{array}$ & Close & Maximum & $\begin{array}{l}\text { Maximu } \\
\mathrm{m}\end{array}$ & Maximum \\
\hline $\begin{array}{l}\text { Similarly, it is not } \\
\text { allowed to } \\
\text { repeatedly delay } \\
\text { the execution of a } \\
\text { kick-off, free-throw, } \\
\text { throw-in or } \\
\text { goalkeeper throw } \\
\text { by your team. }\end{array}$ & $\begin{array}{l}\text { In pairs: front } \\
\text { pass with } \\
\text { reception setting, } \\
\text { loading and } \\
\text { throwing, always } \\
\text { keeping the } \\
\text { movement in } \\
\text { place. }\end{array}$ & $\begin{array}{l}\text { 5vs5 maintaining } \\
\text { continuity against } \\
\text { defence } \\
\text { aggressive. } \\
\text { Attackers must } \\
\text { keep possession of } \\
\text { the ball and } \\
\text { succeed constantly } \\
\text { entering the } 9 \\
\text { meter zone. }\end{array}$ & Close & Maximum & Medium & Maximum \\
\hline
\end{tabular}




\section{DISCUSSION}

The first rule identified concerns the characteristics of the ball. The ball, spherical in shape, must be made of leather or synthetic material. The surface must not be shiny or slippery. The dimensions of the ball, i.e. the circumference and weight, to be used in the different categories are as follows: $58-60$ centimetres and 425475 grams (size 3 ) for the male categories over 16 years, 54-56 centimetres and 325-375 grams (size no. 2) for women over 14 and for men aged 12 to 16 (Mehralitabar et al., 2015). From a technical point of view, it is necessary to propose a space dedicated to awareness exercises (ball-handling) within the training session, thus allowing you to improve grip and reception. A possible proposal of a technical nature to train the sensitivity of the grip could be a pair work with two balls. Where the player hands the ball to the teammate who must exercise a hold from above; the arms are outstretched, the delivery of the ball is always corresponding, one backs up the other advances. A possible variant could be the delivery of the ball to the partner, for example by crossing the pass (Rogulj \& Srhoj, 2009).

From the tactical point of view, it would be appropriate to develop a situational inherent in the maintenance of possession (Tortella et al., 2019). What is evaluated is the ability to manage the ball with or without the presence of the opponent within their own space of action. The commitment from a physical point of view is not very high, but at the same time, maximum executive speed is required. The second rule concerns the handling of the ball. Both when stationary and in motion, it is possible to bounce the ball once on the ground and catch it with one or both hands or, repeatedly bounce it with one hand (dribble) and then catch it or hold it again with one or both hands (Pfeiffer \& Perl, 2006). As soon as the ball is controlled with one or both hands, it must be played within three seconds or after no more than three steps. The dribble or rebound is considered to have started when the player touches the ball with any part of his body and directs it towards the ground); however, it is not sanctioned to touch the ball more than once if the player makes a reception error, for example by failing to control it in an attempt to catch or stop it (Raiola, 2017).

A possible proposal of a technical nature to allow you to familiarize yourself with the offensive collaboration could be a work in pairs with continuous frontal passages in slow running and continuous back and forth, to then go into more detail by varying all the types of passage. In this way, the player will be able to choose the most suitable type of passage for a certain type of action, anticipating the reading of the game. From the performance point of view, the physical effort is medium while the speed level must necessarily be high. Another rule concerns the scoring of a goal. By regulation, only the goalkeeper can enter the goal area. This rule affects both the attacking team and the defending team. In fact, the attacking team must try to make a goal without entering the goalkeeper's area or in any case, if he shoots on the run, the player can enter by jumping into the goalkeeper's area but releasing the ball before it touches the ground within the goal area. Similarly, when a defender enters the goal area with clear defensive intent, the $7 \mathrm{~m}$ shot is granted, commonly known as a "penalty" which is taken with one foot on the $7 \mathrm{~m}$ line (without touching it) and with only the goalkeeper in front, which cannot exceed 4 meters of the door. As for the attacking action, a technical exercise that could underline the need to shoot outside the goal area could be the following: two rows of players on the wing position start alternately and, after having received the throw from a goalkeeper, they circle a cone in the middle of the court and go to throw in elevation outside the 9-meter line (Rogulj et al., 2011).

From a tactical point of view, continuous combinations of three-player attack (full-back-central-full-back) could be developed with change of place without the ball and final shot on goal. As for the defenders, a tactical exercise would be needed to automate those adequate movements to protect the goal without invading the goalkeeper's area. Adequate a situational work of this type with five defenders between six and nine meters 
and five forwards on the circulation positions. Attackers move the ball by performing continuous 1-on-1 actions, penetration, feint stop, change of direction and exit on the same side of the ball. The defenders will have to find the right precautions necessary to intercept the ball without committing a foul. From a performance point of view, the physical commitment is very high both in the offensive and defensive phases. Even the execution of the penalty shot requires appropriate considerations, nothing must be left to chance. At the end of the session it is necessary to dedicate a moment dedicated to penalty shoots, looking for precision rather than the power of the shot. A possible exercise proposal is to assign to each player the task of aiming at a corner of the goal in such a way as to vary the execution of the shot and study all the necessary measures to lower the level of mental pressure and seek maximum efficiency. in the execution of the shot. The regulation also provides for temporary suspensions from the playing field which consist of two-minute periods. At the third temporary exclusion, the player will be disqualified for the rest of the match leaving his team outnumbered (Wallace \& Cardinale, 1997).

A proposal of a technical nature could include a game to improve speed and lateral vision in setting up a counterattack action. One exercise is the following with four defenders arranged in a square around a group of balls: the defenders must prevent the attackers from entering the defensive square to take possession of the balls. From a tactical point of view, a situational three against two would be fine with the defenders arranged in line on 6 meters. The physical effort is high, as is the degree of strength and speed. In marking the opponent, the regulation prohibits the defender from hitting his opponent in any way as well as preventing him from snatching the ball from his hand. A possible situational proposal could be the following: three defenders and three rows of attackers in the positions of outside. The attackers have the task of circulating the ball even under the contact of the defenders; the defenders disturb with slight contacts and conflicts on the person. Every fly a foul is committed against the opponent, a free shot is granted, which is taken at the point where the foul was committed. For fouls committed in the immediate vicinity of the goal area, the freekick from nine meters is beaten with the defence three meters from the ball and the attack all outside the 9meter line. In the practice of shooting on goal an interesting proposal is that of a point game: two points if aiming at the top right or left or top centre; 1 point if bottom right or left. If the player manages to shoot from the outer positions to the left or right, the points obtained can be multiplied by two.

Finally, some rules affect passive play. A team is not allowed to maintain possession of the ball without there being an obvious attempted attack or shot on goal. Similarly, it is not allowed to repeatedly delay the execution of a kick-off, free-throw, throw-in or goalkeeper throw by one's team (Prudente et al., 2010). This behaviour is considered passive play and must be sanctioned with a free throw against the team in possession of the ball, unless this behaviour ceases. At the same time, however, the player in possession of the ball cannot pass the ball to his goalkeeper when he is in the goal area. The passive play rule is intended to avoid unspectacular tactics and intentional wasting of time (Buchheit et al., 2009). To do this, the referees must evaluate and judge passive play unambiguously throughout the match. Forms of passive play can take place in all phases of an attack action, for example when the ball is in circulation, during the construction of the attack or during its final phase. There are several proposals of a technical nature that make it possible to overcome passive play: for example, continuous exchanges of running ball with passing by establishing continuous visual contact with the teammate, or always maintaining the movement in place continuous exchanges of frontal passes with reception setting, loading and throwing (Wagner et al., 2012).

With regard to the back-pass rule, an exercise on crossovers in pairs with a ball would be good: running smoothly over the entire length of the field using a maximum of three passes. Whoever receives the third pass crosses in the run, delivering the ball to the teammate who goes in for penetration. From a tactical point of view, a situational one such as a three on three to free the pivot, attacking the central zone creating the 
advantageous condition for the penetration of a full back, or a five on five maintaining continuity against an aggressive defence (Šibila et al., 2003). Attackers must maintain possession of the ball and constantly be able to enter the nine-meter zone. The connection between these proposals and the rule is very close. From a performance point of view, the physical expenditure is high as well as the degree of strength and speed.

\section{CONCLUSION}

In situation sports it is very useful to have a broad perceptual analysis to make effective decisions. The tactics presuppose the use of technical skills appropriate to the game situation (Sousa et al., 2009). Since the fundamental requirement is represented by the mental and operational assumption, training must necessarily take these aspects into account. It is wrong to think that the ability to resolve the game situation, called "tactical sense", is innate in the player. Instead, it can and must be trained. To bring the player to his maturity it is necessary to proceed step by step, so that the previous learning can be used as a basis for the next one. Before starting to focus on the tactical aspects, it is necessary to have completed the technical maturation. Therefore, the knowledge and correct implementation of the methodological process to achieve complete tactical mastery of the attack action are not sufficient. It takes patience and time if you want to get the desired results.

\section{REFERENCES}

Altavilla G. (2020). Energetic cost in the different running conditions in team sport for the educational teaching method. Sport Science, (14)1:17-20.

Altavilla, G., Raiola, G. (2017). Physiological effects of warm-up and problems related to team sports, Sport Science, 11(2): 83-88.

Buchheit, M., Laursen, P. B., Kuhnle, J., Ruch, D., Renaud, C., \& Ahmaidi, S. (2009). Game-based training in young elite handball players. International journal of sports medicine, 30(04), 251-258. https://doi.org/10.1055/s-0028-1105943

Ceruso, R., Esposito, G., D'Elia, F. (2019). Analysis and evaluation of the qualitative aspects of the young players. Journal of Physical Education and Sport, 19 (5 S):1814-1819.

Debanne, T. (2014). Techniques used by coaches to influence referees in professional team handball. International Journal of Sports Science \& Coaching, 9(3), 433-446. https://doi.org/10.1260/17479541.9.3.433

D'Elia, F., Sgrò, F., \& D'Isanto, T. (2020). The educational value of the rules in volleyball. Journal of Human Sport and Exercise, 15(3proc): S628-S633. https://doi.org/10.14198/hhse.2020.15.Proc3.15

D'Isanto, T., D'Elia, F., Raiola, G., Altavilla, G. (2019). Assessment of sport performance: Theoretical aspects and practical indications, Sport Mont, 17 (1), pp. 79-82. https://doi.org/10.26773/smj.190214

Esposito, G., D'Elia, F., \& Raiola, G. (2020). A Method to Promote the Development of Intelligence and Game Skills in Youth Football. Teoriâ Ta Metodika Fizičnogo Vihovannâ, 20(3), 142-148. https://doi.org/10.17309/tmfv.2020.3.03

Ferrara, F., Izzo, R., Ceciliani, A., Di Tore, A.P. (2019). Pilot study on the testing of Power Glove applied to volleyball. Journal of Human Sport and Exercise, 14(proc.2): S233-S238. https://doi.org/10.14198/ihse.2019.14.Proc2.11

Fradet, L., Kulpa, R., Bideau, B., Multon, F., \& Delamarche, P. (2003). Kinematic simulation of handball throwing. In Proceedings of European Simulation Multiconference (pp. 323-328).

Gao, B., \& He, L. J. (2004). A Preliminary Research on the Dynamic Development of Techniques and Tactics of World Women's Handball [J]. Journal of Beijing Teachers College of Physical Education, 4. 
Granero-Gallegos, A., Gómez-López, M., Rodríguez-Suárez, N., Abraldes, J. A., Alesi, M., \& Bianco, A. (2017). Importance of the motivational climate in goal, enjoyment, and the causes of success in handball players. Frontiers in psychology, 8, 2081. https://doi.org/10.3389/fpsyg.2017.02081

Gutierrez-Davila, M., Rojas, F. J., Ortega, M., Campos, J., \& Parraga, J. (2011). Anticipatory strategies of team-handball goalkeepers. Journal of sports sciences, 29(12), 1321-1328. https://doi.org/10.1080/02640414.2011.591421

Mehralitabar, H., Mirjalali, F., Minoei, A., \& Fadaee, E. (2015). The impact of handball techniques on improving gross motor skills in educable mentally retarded children. International Journal of Sport Studies, 5, 1243-1248.

Pfeiffer, M., \& Perl, J. (2006). Analysis of tactical structures in team handball by means of artificial neural networks. International Journal of Computer Science in Sport, 5(1), 4-14.

Prudente, J., Garganta, J., \& Anguera, M. T. (2010). Methodological Approach to evaluate interactive behaviors in team games: An example in handball. In Proceedings of the 7th International Conference on Methods and Techniques in Behavioral Research (pp. 1-3). https://doi.org/10.1145/1931344.1931385

Raiola, G., Esposito, G., \& Sgrò, F. (2020). The formative value of soccer rules. Journal of Human Sport and Exercise, 15(3proc), S656-S663. https://doi.org/10.14198/hhse.2020.15.Proc3.18

Raiola, G. (2015) Sport skills and mental health, Journal of Human Sport and Exercise, 10 (Specialissue), pp. S369-S376. https://doi.org/10.14198/jhse.2015.10.Proc1.27

Raiola, G. \& D'Isanto T. (2016). Assessment of periodization training in soccer, Journal of Human Sport and Exercise, 11(1proc): 267-278. https://doi.org/10.14198/hhse.2016.11.Proc1.19

Raiola, G. (2017) Motor learning and teaching method, Journal of Physical Education and Sport, 17, art. no. 236, pp. 2239-2243.

Rogulj, N., Srhoj, V., \& Srhoj, L. (2004). The contribution of collective attack tactics in differentiating handball score efficiency. Collegium antropologicum, 28(2), 739-746.

Rogulj, N., Vuleta, D., Milanovic, D., Cavala, M., \& Foretic, N. (2011). The efficiency of elements of collective attack tactics in Handball. Kinesiologia Slovenica, 17(1), 5.

Rogulj, N., \& Srhoj, V. (2009). The influence of the elements of the collective attack tactics on handball match outcome. Fizička kultura (Skopje), 37(1), 15-20.

Schrapf, N., \& Tilp, M. (2013). Action sequence analysis in team handball. Journal of Human Sport \& Exercise. 8(proc3). https://doi.org/10.4100/ihse.2013.8.Proc3.07

Severino, N.C., Cassese, F.P., Ceciliani, A., D'Elia, F., Di Tore, A.P. (2019). Psychophysical benefits of recreational five-a-side football, Journal of Human Sport and Exercise, 14(proc.2): S206-S214. https://doi.org/10.14198/ihse.2019.14.Proc2.07

Sgrò, F., Quinto, A., Platania, F., Lipoma, M. (2019). Assessing the impact of a physical education project based on games approach on the actual motor competence of primary school children. Journal of Physical Education and Sport, 19:781-786.

Sgrò, F., Quinto, A., Messana, L., Pignato, S., Lipoma, M. (2017). Assessment of gross motor development level in italian primary school children. Journal of Physical Education and Sport, 17(3): 1954-1959.

Šibila, M., Pori, P., \& Bon, M. (2003). Basic kinematic differences between two types of jump shot techniques in handball. Universitatis Palackianae Olomucensis Gymnica, 33(1), 19-26.

Sousa, A., Santiago, C., Reis, L. P., \& Estriga, M. L. (2009). Automatic detection and tracking of handball players. Proceedings of the VipIMAGE, 213-219.

Skarbalius, A., Pukènas, K., \& Vidūnaitè, G. (2013). Sport performance profile in men's European modern handball: discriminant analysis between winners and losers. Baltic Journal of Sport and Health Sciences, 3(90). https://doi.org/10.33607/bjshs.v3i90.168 
Tortella, P., Haga, M., Ingebrigtsen, J.E., Sigmundsson, H., Fumagalli, G.F. (2019). Comparing free play and partly structured play in 4-5 years old children in an outdoor playground. Frontiers in public health, 7, 197. https://doi.org/10.3389/fpubh.2019.00197

Wallace, M. B., \& Cardinale, M. (1997). Conditioning for team handball. Strength \& Conditioning Journal, 19(6), 7-12.

Wagner, H., Pfusterschmied, J., von Duvillard, S. P., \& Müller, E. (2011). Performance and kinematics of various throwing techniques in team-handball. Journal of sports science \& medicine, 10(1), 73.

Wagner, H., Pfusterschmied, J., Klous, M., von Duvillard, S. P., \& Müller, E. (2012). Movement variability and skill level of various throwing techniques. Human movement science, 31(1), 78-90. https://doi.org/10.1016/j.humov.2011.05.005

Zhao, H. Q., Sun, J., Hua, Y. M., \& Jin, J. C. (2008). A Study of Data Mining Technology Applied on Technique and Tactic Analysis of Sport Competitions. Journal of Beijing Sport University, 5, 046. 